LUCIANO FERNANDES LOURES ${ }^{1}$

EDUardo Batista CÂNDIDO ${ }^{2}$

Paula Vieira Teixeira Vidigal ${ }^{3}$

Mariana Ataydes Leite Seabra ${ }^{4}$

Luiz Armando Cunha de Marco 5

AGNALDO LoPES DA SILVA-FILHO ${ }^{2,6}$

Original Article

Keywords

Uterine cervical neoplasms Immunohistochemistry

Gene expression

Antigens, neoplasm

Palavras-chave

Neoplasias do colo do útero Imunohistoquímica Expressão gênica Antígenos de neoplasias

\section{PTEN expression in patients with carcinoma of the cervix and its association with p53, Ki-67 and CD31}

\author{
Expressão do PTEN em pacientes com carcinoma de colo \\ uterino e sua associaçấo com p53, Ki-67 e CD31
}

Abstract

PURPOSE: To investigate protein expression and mutations in phosphatase and tensin homolog (PTEN) in patients with stage IB cervical squamous cell carcinoma (CSCC) and the association with clinical-pathologic features, tumor p53 expression, cell proliferation and angiogenesis. METHODS: Women with stage IB CSCC ( $\mathrm{n}=20$ - Study Group) and uterine myoma ( $n=20$ - Control Group), aged 49.1 1.7 years (mean \pm standard deviation, range 27-78 years), were prospectively evaluated. Patients with cervical cancer were submitted to Piver-Rutledge class III radical hysterectomy and pelvic lymphadenectomy and patients in the Control Group underwent vaginal hysterectomy. Tissue samples from the procedures were stained with hematoxylin and eosin for histological evaluation. Protein expression was detected by immunohistochemistry. Staining for PTEN, p53, Ki-67 and CD3 1 was evaluated. The intensity of PTEN immunostaining was estimated by computer-assisted image analysis, based on previously reported protocols. Data were analyzed using the Student's t-test to evaluate significant differences between the groups. Level of significance was set at $p<0.05$. RESULTS: The PTEN expression intensity was lower in the CSCC group than in the Control (benign cervix) samples (150.5 \pm 5.2 versus 204.2 $\pm 2.6 ; p<0.001$ ). Our study did not identify any mutations after sequencing all nine PTEN exons. PTEN expression was not associated with tumor expression of p53 ( $p=0.9$ ), CD3 1 ( $p=0.8$ ) or Ki-67 ( $p=0.3$ ) or clinical-pathologic features in patients with invasive carcinoma of the cervix. CONCLUSIONS: Our findings demonstrate that the PTEN protein expression is significantly diminished in CSCC.

\section{Resumo}

OBJETIVO: $\bigcirc$ objetivo do estudo foi investigar a expressão e mutações do PTEN em pacientes com Carcinoma de Células Escamosas (CCE) de Colo do Útero com estadiamento IB e sua associação com fatores prognósticos, expressão do p53, proliferação celular e angiogênese. MÉTODOS: Mulheres com diagnóstico de CCE de colo uterino em estágio IB $(n=20)$ (casos) e mioma uterino ( $n=20)$ (controle) com idade de 49.1 1.7 foram acompanhadas. As pacientes com câncer de colo do útero foram submetidas a histerectomia Piver-Rutledge classe III associada a linfadenectomia pélvica e aquelas com mioma uterino a histerectomia vaginal. Amostras de tumor e colo normal foram retiradas para avaliação histológica e marcação imuno-histoquímica das proteínas PTEN, p53, ki-67 e CD 3. A intensidade imunohistoquímica do PTEN foi estimada por processamento de imagem digital a partir de protocolos pré-estabelecidos. Os dados foram analisados através do teste de qui - quadrado $\left(\chi^{2}\right)$. $\bigcirc$ nível de significância foi considerado quando $p<0,05$. RESULTADOS: A expressão do PTEN estava diminuída no grupo de pacientes com CCE em comparação ao grupo controle (150.5 \pm 5.2 versus 204.2 $\pm 2.6 ; \mathrm{p}<0.001$ ). Nenhuma mutação no seqüenciamento genético dos nove exons do PTEN foi encontrada. Não houve associação estatisticamente significativa entre a expressão do PTEN e a expressão do p53 (p=0,969), Ki-67 ( $p=0.283)$ e CD 31 ( $p=0.817)$ ou fatores prognósticos anátomo-clínicos nas pacientes com carcinoma invasor do colo uterino. CONCLUSÕES: Este estudo demonstrou que o PTEN estava significativamente diminuído nas pacientes com CCE.
Correspondence

Agnaldo Lopes Silva-Filho

Department of Obstetrics and Gynecology,

Universidade Federal de Minas Gerois Avenida Professor Alfredo Balena, 190 - Santa Efigênia

CEP: $30130-100$

Belo Horizonte (MG), Brazi

Received

03/09/2014

Accept with modifications

$04 / 23 / 2014$
Hospital das Clínicas da Universidade Federal de Minas Gerais - UFMG - Belo Horizonte (MG), Brazil.

'Department of Obstetrics and Gynecology, Universidade Federal de Juiz de Fora - UFJF - Juiz de Fora (MG), Brazil.

2Department of Obstetrics and Gynecology, Universidade Federal de Minas Gerais - UFMG - Belo Horizonte (MG), Brazil.

${ }^{3}$ Department of Pathology, Universidade Federal de Minas Gerais - UFMG - Belo Horizonte (MG), Brazil.

${ }^{4}$ Clinical Hospital, Faculdade de Medicina, Universidade Federal de Minas Gerais - UFMG - Belo Horizonte (MG), Brazil.

${ }^{5}$ Department of Surgery, Universidade Federal de Minas Gerais - UFMG - Belo Horizonte (MG), Brazil.

-Department of Obstetrics, Gynecology and Mastology, Faculdade de Medicina de Botucatu, Universidade Estadual Paulista "Júlio de Mesquita Filho" - UNESP - Botucatu (SP), Brazil.

Conflicts of interests: none. 


\section{Introduction}

Cervical cancer is a worldwide public health problem, with an incidence of 530,232 new cases and 275,008 deaths every year ${ }^{1}$. Most cases occur in undeveloped countries where no effective screening systems are available ${ }^{2}$. In Brazil, 17,540 new cases were estimated to occur in 2012, making it the third most common malignancy and the fourth leading cause of death among women ${ }^{3}$.

Persistent infection with human papillomavirus (HPV) plays a critical role in cervical carcinogenesis. However, $\mathrm{HPV}$ infection alone is not sufficient to induce malignant transformation, and additional genetic or epigenetic changes in tumor cells are required ${ }^{4,5}$. The development and progression of cervical squamous cell carcinoma (CSCC) are likely to be associated with the loss of growth suppression, increased cell growth rates, and angiogenesis ${ }^{6,7}$. These combinations of genetic abnormalities generate cells that divide more rapidly or evade cell death, thus liberating them from growth control and cell cycle checkpoints.

Phosphatase and tensin homolog (PTEN) is a tumor suppressor gene localized on chromosome 10 (10q23.3) in a region that is often related to loss of heterozygosis and consequent predisposition to carcinogenesis in a number of malignancies ${ }^{8-10}$. Genetic, epigenetic and protein expression alterations in PTEN have been described in several types of tumors such as brain, prostate, breast, thyroid and endometrial tumors ${ }^{11-14}$. PTEN phosphatase is a negative regulator of the $\mathrm{Akt} / \mathrm{PKB}$ survival pathway, which is over-expressed in $\mathrm{CSCC}^{15}$. Mutations are common in many human cancers, but the loss of heterozygosity, a genomic deletion and punctual mutations in PTEN and their associations with squamous cells carcinoma are controversial ${ }^{15-19}$.

The role of PTEN in cervical carcinogenesis has not been clearly defined and there is no general agreement on the mechanism related to the reduction of PTEN expression in cervical cancer ${ }^{20}$. Therefore, the purpose of this study was to investigate protein expression and mutations in PTEN in patients with stage IB CSCC and the association with clinical-pathologic features, tumor p53 expression, cell proliferation and angiogenesis.

\section{Methods}

Women with stage IB CSCC ( $\mathrm{n}=20$ - Study Group) and uterine myoma ( $\mathrm{n}=20$ - Control Group), aged $49.1 \pm 1.7$ years (mean \pm standard deviation, range $27-78$ years) were prospectively evaluated. The study was performed in accordance with the Ethical Committee for Research in Human Beings guidelines of the institution. Informed consent was obtained from all included patients and the research was conducted in accordance with the Declaration of Helsinki revised in 2008.
Patients with CSCC underwent class III Piver-Rutledge radical hysterectomy and pelvic lymphadenectomy. This was the primary treatment for all patients because none had previously been treated with radiotherapy and/or chemotherapy. The clinical stage was defined preoperatively by pelvic examination under general anesthesia according to the International Federation of Gynecology and Obstetrics (FIGO) recommendations ${ }^{21,22}$. Vaginal hysterectomy was performed for uterine myomas according to the modified Heaney technique.

Tissue samples were fixed in $10 \%$ neutral-buffered formalin, embedded in paraffin, and stained with hematoxylin and eosin for histological evaluation. Histological specimens were analyzed by the same pathologists according to the recommendations of the American Society of Pathologists ${ }^{23}$. Clinical-pathologic characteristics, such as tumor size, differentiation grade, lymphatic vascular space invasion (LVSI), parametrial involvement and pelvic lymph node status, were recorded.

\section{Immunohistochemistry}

Tissue sections from CSCC and normal mucosa were stained with PTEN, p53, Ki-67 and CD31 antiserum. Briefly, $4 \mu \mathrm{m}$ paraffin-embedded sections were deparaffinized in xylene and hydrated with graded ethanol solutions. Endogenous peroxidase activity was blocked with 3\% $\mathrm{H}_{2} \mathrm{O}_{2}$ in water for $10 \mathrm{~min}$. Heat-induced epitope retrieval was performed with $1 \mathrm{mM}$ EDTA buffer $(\mathrm{pH}=8.0)$ for $30 \mathrm{~min}$ in a steamer at $96^{\circ} \mathrm{C}$. Primary polyclonal rabbit antisera were used at a 1:100 dilution for PTEN, p53, and $\mathrm{Ki}-67$ and a 1:40 dilution for CD31 antiserum for $18 \mathrm{~h}$ at $4^{\circ} \mathrm{C}$. This was followed by incubation with a labeled streptavidin-biotin kit, the NovoLinkTM Max Polymer Detection System (Novocastra, United Kingdom). Peroxidase activity was developed with DAB (Sigma, St Louis, MI) with timed monitoring using a positive control sample. Sections were then counterstained with hematoxylin, dehydrated and mounted.

\section{Analysis of phosphatase and tensin homolog staining}

The intensity of PTEN immunostaining was estimated by computer-assisted image analysis, based on previously reported protocols. Pictures from 10 different fields of each sample were taken with a Leica DMLB microscope and digitalized using the Leica IM50 software, version 4.0. Digital images were processed with Adobe Photoshop (Adobe Systems, USA), converted to grayscale and inverted. Images were then exported to Image-Tool software (version 3.0, University of Texas Health Science Center, San Antonio, USA) for quantitative analysis. For this proposal, 10 epithelial cell nuclei from 10 different fields, totaling 100 nuclei from each patient, were traced and had their area measured. Pixel intensity was determined for the 
traced areas. For each field, one nucleus with an evident nucleolus was randomly chosen for measurement, and the next nine consecutive nuclei were quantified. Out-of-focus and altered-form nuclei were not considered. Background intensity was determined by tracing an unlabeled area adjacent to the measured cells. The final pixel intensity was calculated by subtracting the values detected in the labeled nuclei from the background (Figure 1).

\section{Phosphatase and tensin homolog sequencing}

Genomic DNA was isolated from CSCC tissue samples according to a proteinase K-based protocol. After DNA isolation, exons 1 through 9 of PTEN were amplified by PCR with specific primers for each region. For the PCR reactions, $2 \mu \mathrm{L}$ of DNA at $30 \mathrm{ng} / \mu \mathrm{L}$ were mixed with $2.5 \mu \mathrm{L}$ of $10 \mathrm{X}$ IIB Buffer $(40 \mathrm{mM} \mathrm{NaCl}$;

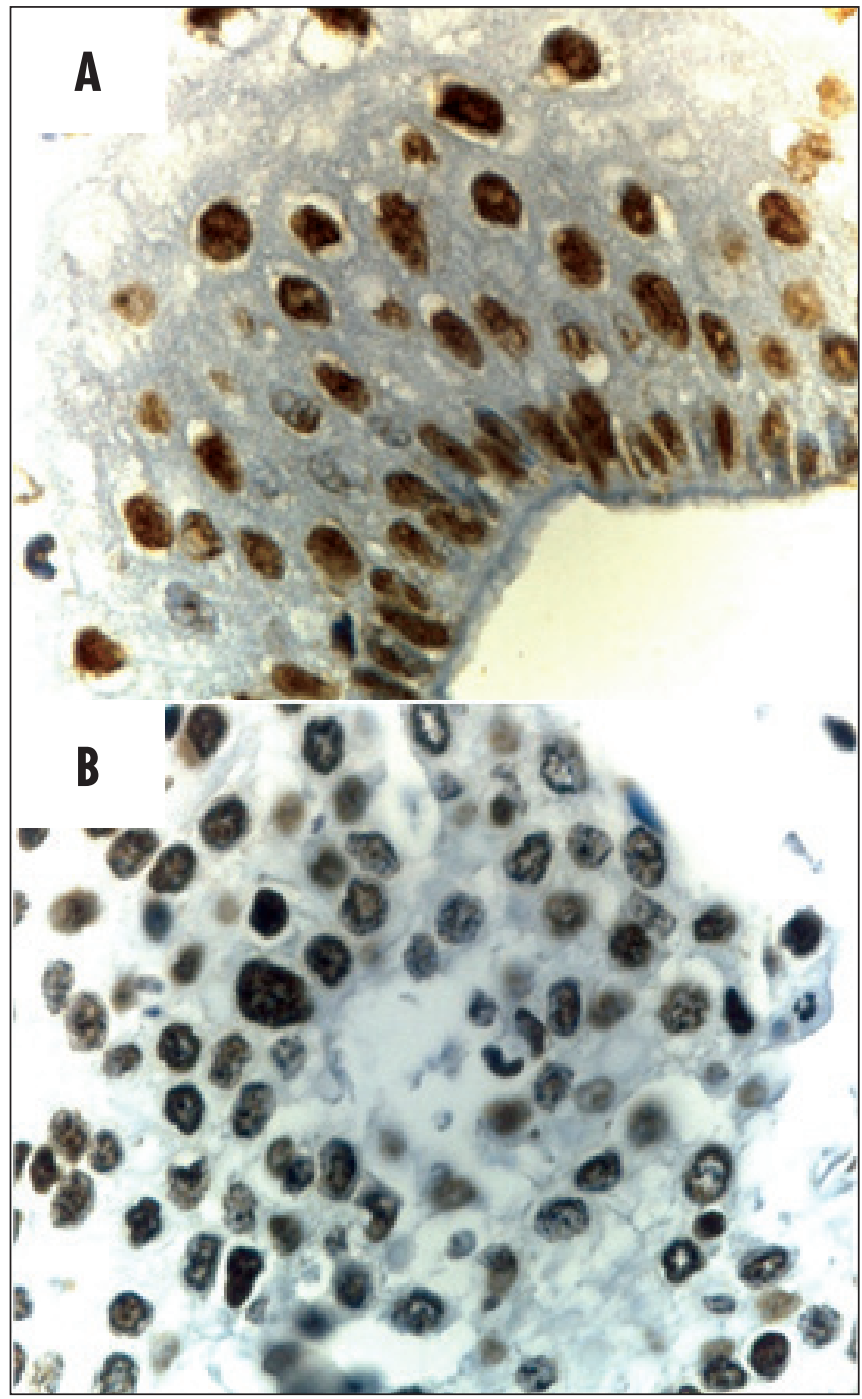

Figure 1. Photomicrographs of a squamous cell carcinoma with phosphatase and tensin homolog nuclear immunostaining in normal cervical epithelium (A) and cervical squamous cell carcinoma (B). The markup is brown. Note the reduction in intensity of expression in the cervical squamous cell carcinoma as compared to control (400X magnification)
$10 \mathrm{mM}$ TrisHCl pH=8.4; $0.1 \%$ Triton $\mathrm{X}-100 ; 1.5 \mathrm{mM}$ $\left.\mathrm{MgCl}_{2}\right), 2.5 \mu \mathrm{L}$ of $0.2 \mathrm{mM}$ dNTPs, $0.5 \mu \mathrm{L}$ of each primer at $10 \mathrm{pmol} / \mu \mathrm{L}$ and $0,25 \mu \mathrm{L}$ of Taq polymerase $(0,625 \mathrm{U})$, for a final volume of $25 \mu \mathrm{L}$. Samples were amplified using an Eppendorf Mastercycler ${ }^{\circledR}$ (Hamburg, Germany) gradient thermocycler at $94^{\circ} \mathrm{C}$ for 3 minutes followed by 35 cycles of $94^{\circ} \mathrm{C}$ for 30 seconds, $55^{\circ} \mathrm{C}$ for 30 seconds, $72^{\circ} \mathrm{C}$ for 30 seconds and a final extension time at $72^{\circ} \mathrm{C}$ for 5 minutes. PCR products were purified using Illustra GFX PCR DNA and Gel Band Purification Kit (GE Healthcare), following the manufacturer's protocol, and were visualized on a silver-stained $6,5 \%$ polyacrylamide gel. Sequences were obtained using an ABI 3130 Genetic Analyzer (Applied Biosystems). Bidirectional sequence data were analyzed with Sequencher 4.9 software, and the analysis was followed by a manual review.

\section{Analysis of p53, Ki-67, and CD31 staining}

All slides were examined under light microscopy. Staining for p53, Ki-67, and CD31 were evaluated according to the number of positively stained cells by a single pathologist who was blinded to the clinical data of the patients. This was performed by classifying the protein expression into 4 categories for statistical purposes as follows: grade $1-0$ to $25 \%$ expression; grade $2-26$ to $50 \%$ expression; grade $3-51$ to $75 \%$ expression; and grade 4 - greater than $75 \%$ expression.

\section{Statistical analyses}

Statistical analyses were performed with Statistical Package for the Social Sciences (SPSS) 18.0 software (SPSS Inc., Chicago, IL, USA). Data were analyzed using Student's $t$-test to evaluate significant differences between the groups. The level of significance was set at $\mathrm{p}<0.05$.

Power calculations showed that the sample size $(n=20)$ allowed a minimal detectable difference of $35 \%$ between the 2 prevalence rates, with a power of $80 \%$ and a type I error of $5 \%$.

\section{Results}

The clinical stage (FIGO) was IB1 in 14 patients $(70 \%)$ and IB2 in 6 patients $(30 \%)$. The tumors were well differentiated (G1) in $1(5 \%)$ patient, moderately differentiated (G2) in $15(75 \%)$ patients and poorly differentiated in $4(20 \%)$ patients. Lymphatic vascular invasion was present in 4 patients (20\%).

The PTEN expression intensity was lower in the CSCC group than in the benign cervix samples $(150.5 \pm 5.2$ versus 204.2 $\pm 2.6 ; \mathrm{p}<0.001$ ) (Figure 2). No associations were identified between tumor PTEN expression and tumor stage $(\mathrm{p}=0.3)$, grade of differentiation $(\mathrm{p}=0.4)$, presence of lymphatic vascular invasion $(\mathrm{p}=0.2)$, parametrium 
involvement $(p=0.6)$ or pelvic lymph node metastasis $(\mathrm{p}=0.9)$ in patients with invasive carcinoma of the cervix (Study Group) (Table 1).

All 9 PTEN exons were sequenced, and we were unable to find modifications in the PTEN DNA sequence in the 20 CSCC samples included in the study or in the normal cervical squamous epithelial sample used as control.

PTEN expression was not associated with tumor expression of $\mathrm{p} 53(\mathrm{p}=0.9), \mathrm{CD} 31(\mathrm{p}=0.8)$ or Ki-67 $(\mathrm{p}=0.3)$ in patients with invasive carcinoma of the cervix (Figure 3 ).

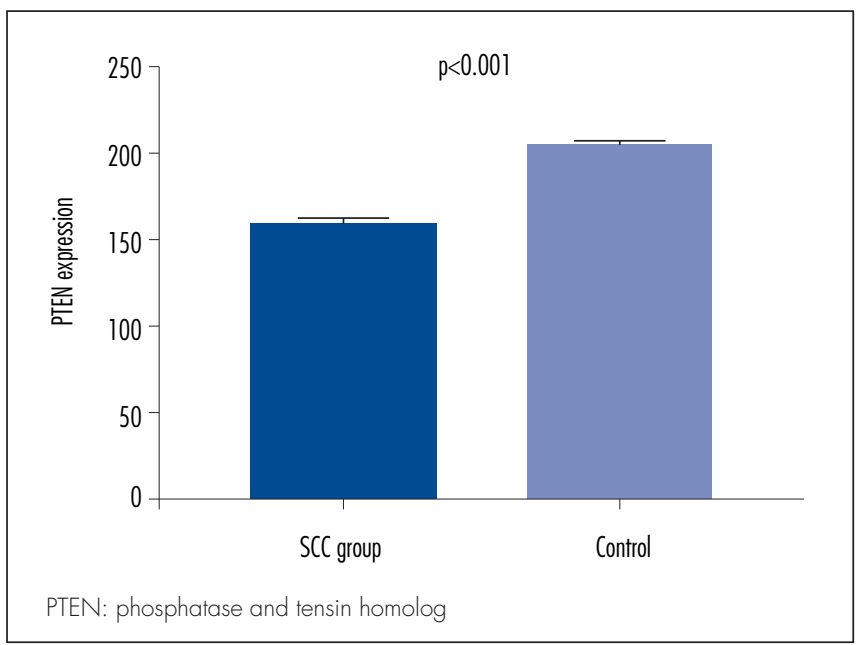

Figure 2. Expression of PTEN intensity in benign cervix (control group) and in the tumor (study group)

Table 1. Association of tumor size, grade of differentiation, presence of lymphatic vascular invasion, parametrium involvement and pelvic lymph node metastasis with tumor phosphatase and tensin homolog expression in patients with squamous cell carcinoma of the cervix

\begin{tabular}{lcc}
\hline \multirow{2}{*}{ Variables } & \multicolumn{2}{c}{ PTEN } \\
\cline { 2 - 3 } & Mean \pm SD & p-value \\
\hline Clinical stage & & 0.3 \\
IB 1 & $150.8 \pm 6.4$ & \\
IB2 & $159 \pm 4.9$ & \\
Tumor grade & & 0.4 \\
$\quad$ G1 and G2 & $150.5 \pm 15.9$ & \\
G3 & $159.2 \pm 7.7$ & \\
LVSI & & 0.2 \\
$\quad$ No & $150.2 \pm 14.8$ & \\
$\quad$ Yes & $163.2 \pm 11.1$ & \\
Parametrial invasion & & 0.1 \\
$\quad$ No & $147.6 \pm 13.6$ & \\
Yes & $164.4 \pm 10.5$ & \\
Lymph node space metastasis & & 0.9 \\
$\quad$ Yes & $152.7 \pm 13.2$ \\
$\quad$ No & $154.3 \pm 16.5$ & \\
\hline
\end{tabular}

PTEN: phosphatase and tensin homolog; SD: standard deviation

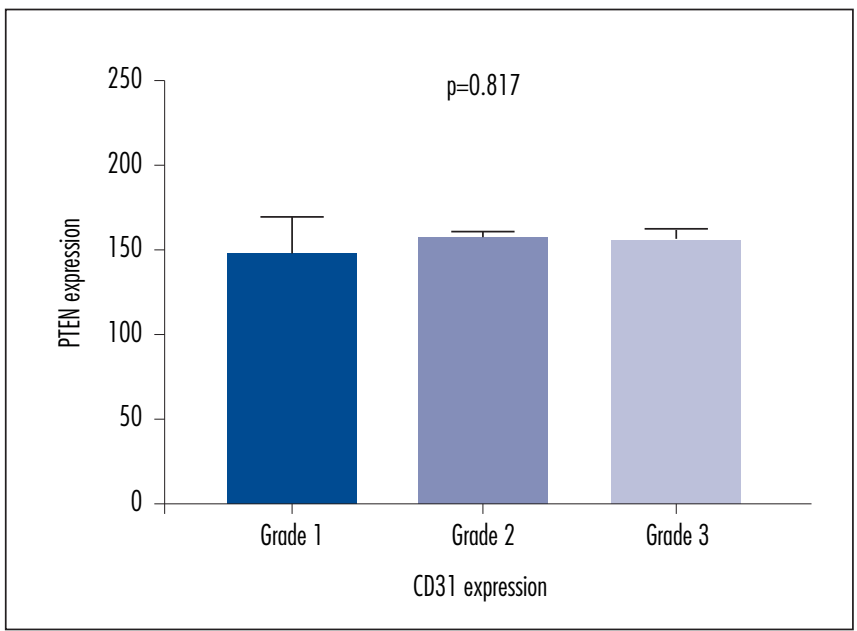

Figure 3. Association between PTEN expression and CD3 1 tumor expression in patients with squamous cell carcinoma of the cervix

\section{Discussion}

PTEN genetic alterations occur in multiple types of cancer, such as brain, prostate, breast, thyroid and endometrial tumors. Thus, PTEN inactivation may play an important role in the pathogenesis of a variety of human malignancies ${ }^{24}$. The present study found PTEN protein significantly diminished in CSCC compared to control. This suggests that the loss of PTEN expression plays a role in cervical carcinogenesis. Previous reports have also demonstrated that PTEN expression is progressively reduced along a continuum from normal epithelium to squamous cell carcinoma ${ }^{25,26}$.

Our study did not identify mutations after sequencing all 9 PTEN exons, even in the hot spot in exon 5. Structural changes of PTEN in cervical carcinomas do not appear to be common. Previous reports have not identified mutations in the PTEN gene in this type of cancer $^{8,19}$. However, Poetsch et al. ${ }^{27}$ demonstrated PTEN mutations in $23 \%$ of head and neck SCC tumor samples, and Kurose et al. ${ }^{28}$ found intragenic PTEN mutations in $15 \%(3 / 20)$ of cervical tumors. PTEN mutations were frequently found in cancers arising from the endometrium $^{29,30}$, $^{\text {brain }}{ }^{31}$ and prostate ${ }^{32}$. Rashmi et al. ${ }^{33}$ found results with activating PIK3CA (E545K, E542K) and inactivating PTEN (R233) mutations were identified in human cervical cancer. An analysis of PTEN gene in squamous cell carcinomas from other sites also found that PTEN is not frequently mutated in the lung ${ }^{34}$, cervix $^{14}, \operatorname{skin}^{35}$, head and neck ${ }^{36}$ or esophagus ${ }^{37}$. Although numerous somatic mutations have been localized in the PTEN gene, these only occur in a minority of tumors, which indicates that alternative mechanisms of PTEN inactivation, both genetic and non-genetic, must exist. 
Our study did not focus on the role of epigenetic changes of PTEN in the development of squamous cell carcinoma. The future challenge is to further understand the roles of these possible epigenetic mechanisms of PTEN alteration and their biological relevance is a challenge for the future. PTEN inactivation via epigenetic mechanisms was first demonstrated in prostate cancer cell lines ${ }^{38}$ and later found in prostate cancer and melanoma ${ }^{39}$. Ojesina et al. ${ }^{40}$ implicated somatic mutations in PIK3CA, PTEN, TP53, STK11 and KRAS as well as several copy-number alterations in the pathogenesis of cervical carcinomas and reported whole-exome sequencing analysis of 115 cervical carcinoma-normal paired samples, transcriptome sequencing of 79 cases and whole-genome sequencing of 14 tumour-normal pairs. Previously unknown somatic mutations in 79 primary squamous cell carcinomas include recurrent $\mathrm{E} 322 \mathrm{~K}$ substitutions in the MAPK1 gene (8\%), inactivating mutations in the HLA-B gene (9\%), and mutations in EP300 (16\%), FBXW7 (15\%), NFE2L2 (4\%), P53 (5\%) and ERBB2 $(6 \%)$. The association of poor prognosis with PTEN aberration has also been reported previously in glioma ${ }^{41}$ and tongue carcinoma ${ }^{42}$. Whether PTEN methylation contributes to the development of cervical cancer and affects the prognosis has not been elucidated. Cheung et al. ${ }^{8}$ found that PTEN methylation was significantly associated with reduced total and disease-free survival and suggested that tumors without normal PTEN functioning may be more aggressive.

In the present report, we analyzed p53, CD31 and Ki-67 expression and their association with PTEN expression in CSCC. We believe that our study is the first report describing PTEN expression in a benign cervix and cervical cancer and its association with those biomarkers. The roles of $\mathrm{p} 53$ and PTEN in cervical carcinogenesis have been addressed, but little is known about the interaction of these proteins in cervical cancer. PTEN has been shown to directly associate with p53, increasing its stability, protein levels, and transcriptional activity ${ }^{43}$. The expression of $\mathrm{Ki}-67$ and $\mathrm{CD} 31$ was assessed in various grades of cervical intraepithelial neoplasia (CIN) to evaluate their potential to predict the extent of possible damage to the epithelium and CIN progression. Ki-67, a non-histone protein with short half-life, is expressed in the nuclei of proliferating cells, becoming a marker of cell prolifera$\operatorname{tion}^{44,45}$. Angiogenesis is correlated with the potential for solid tumor metastasis. CD31 expression is related to neovascularization and may be associated with the clinical course of the cervical tumor ${ }^{46}$. No significant association was found between PTEN and other biomarkers, suggesting that the loss of PTEN expression is sufficient to facilitate tumorigenesis, but different mechanisms may explain cervical carcinogenesis.

We were not able to identify any clinical or pathologic factors associated with PTEN expression in CSCC specimens. Given the limited number of samples investigated, our ability to detect prognostic associations of modest size was limited. The association between PTEN expression and disease outcome warrants further investigation in a larger study cohort along with the analysis of prognostic factors.

In conclusion, our findings demonstrate that the PTEN protein is significantly diminished in CSCC. Therefore, we suggest that PTEN plays an important role in carcinogenesis in the uterine cervix.

Interestingly, no mutations in PTEN have been identified. Alternative mechanisms of PTEN dysregulation, such as epigenetic mechanisms, which result in clinical manifestations, must therefore exist. Additional functions of this molecule will certainly be uncovered and these should help to further elucidate the importance of this protein in human health and disease.

\section{References}

1. International Agency for Research on Cancer. World Health Organization. GLOBOCAN 2012: estimated cancer incidence, and mortality and prevalence worldwide in 2012 [Internet]. Lyon: IARC; 2013 [cited 2014 Mar 20]. Available from: http://globocan.iarc.fr/ Default.aspx

2. Waggoner SE. Cervical cancer. Lancet. 2003;361(9376): $2217-25$

3. Brasil. Ministério da Saúde. Instituto Nacional de Câncer José Alencar Gomes da Silva. Coordenação Geral de Ações Estratégicas. Coordenação de Prevenção e Vigilância. Estimativa 2012: incidência de câncer no Brasil [Internet]. Rio de Janeiro: INCA; 2011 [citado 2012 Maio 15]. Disponível em: http:// portal.saude.sp.gov.br/resources/ses/perfil/gestor/homepage/ estimativas-de-incidencia-de-cancer-2012/estimativas_incidencia_ cancer_2012.pdf
4. Castellsagué $X$. Natural history and epidemiology of HPV infection and cervical cancer. Gynecol Oncol. 2008;1 10(3 Suppl 2):S4-7.

5. Giarnieri E, Zanesi N, Bottoni A, Alderisio M, Lukic A, Vecchione $A$, et al. Oncosuppressor proteins of fragile sites are reduced in cervical cancer. Cancer Lett. 2010;289(1):40-5.

6. Hanahan D, Weinberg RA. The hallmarks of cancer. Cell. 2000; 100(1):57-70.

7. Hahn WC, Weinberg RA. Rules for making human tumor cells. $N$ Engl J Med. 2002;347(20):1593-603.

8. Cheung TH, Lo KW, Yim SF, Chan LK, Heung MS, Chan CS, et al. Epigenetic and genetic alternation of PTEN in cervical neoplasm. Gynecol Oncol. 2004;93(3):621-7.

9. Tamguney T, Stokoe D. New insights into PTEN. J Cell Sci. 2007; 120(P+ 23):4071-9. 
10. Vazquez F, Ramaswamy S, Nakamura N, Sellers WR. Phosphorylation of the PTEN tail regulates protein stability and function. Mol Cell Biol. 2000;20(14):5010-8.

11. Alvarez-Nuñez F, Bussaglia E, Mauricio D, Ybarra J, Vilar M, Lerma $E$, et al. PTEN promoter methylation in sporadic thyroid carcinomas. Thyroid. 2006;16(1):17-23.

12. Li J, Yen C, Liaw D, Podsypanina K, Bose S, Wang SI, et al. PTEN, a putative protein tyrosine phosphatase gene mutated in human brain, breast, and prostate cancer. Science. 1997;275(5308):1943-7.

13. Mutter GL, Lin MC, Fitzgerald JT, Kum JB, Baak JP, Lees JA, et al. Altered PTEN expression as a diagnostic marker for the earliest endometrial precancers. J Natl Cancer Inst. 2000;92(1 1):924-30.

14. Tashiro H, Blazes MS, Wu R, Cho KR, Bose S, Wang SI, et al. Mutations in PTEN are frequent in endometrial carcinoma but rare in other common gynecological malignancies. Cancer Res. 1997;57(18):3935-40.

15. Sansal I, Sellers WR. The biology and clinical relevance of the PTEN tumor suppressor pathway. J Clin Oncol. 2004;22(14):2954-63.

16. Gasparotto D, Vukosavljevic T, Piccinin S, Barzan L, Sulfaro S, Armellin $M$, et al. Loss of heterozygosity at $10 q$ in tumors of the upper respiratory tract is associated with poor prognosis. Int J Cancer. 1999;84(4):432-6.

17. Harima Y, Sawada S, Nagata K, Sougawa M, Ostapenko V, Ohnishi T. Mutation of the PTEN gene in advanced cervical cancer correlated with tumor progression and poor outcome after radiotherapy. Int J Oncol. 2001;18(3):493-7.

18. Henderson YC, Wang E, Clayman GL. Genotypic analysis of tumor suppressor genes PTEN/MMAC1 and p53 in head and neck squamous cell carcinomas. Laryngoscope. 1998;108(10):1553-6.

19. Su TH, Chang JG, Perng LI, Chang CP, Wei HJ, Wang NM, et al. Mutation analysis of the putative tumor suppressor gene PTEN/MMAC1 in cervical cancer. Gynecol Oncol. 2000;76(2): 193-9

20. Vázquez-Ulloa $E$, Lizano $M$, Avilés-Salas A, Alfaro-Moreno $E$, Contreras-Paredes A. Abnormal distribution of hDlg and PTEN in premalignant lesions and invasive cervical cancer. Gynecol Oncol. $2011 ; 122(3): 663-8$.

21. Benedet JL, Bender H, Jones H 3rd, Ngan HY, Pecorelli S. FIGO staging classifications and clinical practice guidelines in the management of gynecologic cancers. FIGO Committee on Gynecologic Oncology. Int J Gynaecol Obstet. 2000;70(2):209-62.

22. Shepherd JH. Cervical and vulva cancer: changes in FIGO definitions of staging. Br J Obstet Gynaecol. 1996; 103(5):405-6.

23. Kamura T, Shigematsu T, Kaku T, Shimamoto T, Saito T, Sakai K, et al. Histopathological factors influencing pelvic lymph node metastases in two or more sites in patients with cervical carcinoma undergoing radical hysterectomy. Acta Obstet Gynecol Scand. 1999;78(5):452-7.

24. Nakanishi A, Kitagishi Y, Ogura Y, Matsuda S. The tumor suppressor PTEN interacts with p53 in hereditary cancer (Review). Int J Oncol. 2014;44(6):1813-9.

25. Lee JS, Choi YD, Lee JH, Nam JH, Choi C, Lee MC, et al. Expression of PTEN in the progression of cervical neoplasia and its relation to tumor behavior and angiogenesis in invasive squamous cell carcinoma. J Surg Oncol. 2006;93(3):233-40

26. Qi M, Anderson AE, Chen DZ, Sun S, Auborn KJ. Indole-3carbinol prevents PTEN loss in cervical cancer in vivo. Mol Med. 2005; 11 (1-12):59-63.

27. Poetsch $M$, Lorenz $G$, Kleist B. Detection of new PTEN/MMAC1 mutations in head and neck squamous cell carcinomas with loss of chromosome 10. Cancer Genet Cytogenet. 2002;132(1):20-4.
28. Kurose K, Zhou XP, Araki T, Eng C. Biallelic inactivating mutations and an occult germline mutation of PTEN in primary cervical carcinomas. Genes Chromosomes Cancer. 2000;29(2):166-72.

29. Kong D, Suzuki A, Zou TT, Sakurada A, Kemp LW, Wakatsuki S, et al. PTEN 1 is frequently mutated in primary endometrial carcinomas. Nat Genet. 1997;17(2): 143-4.

30. Husseinzadeh N, Husseinzadeh HD. mTOR inhibitors and their clinical application in cervical, endometrial and ovarian cancers: a critical review. Gynecol Oncol. 2014;133(2):375-81.

31. Boström J, Cobbers JM, Wolter M, Tabatabai G, Weber RG, Lichter $P$, et al. Mutation of the PTEN (MMAC1) tumor suppressor gene in a subset of glioblastomas but not in meningiomas with loss of chromosome arm 10q. Cancer Res. 1998;58(1):29-33.

32. Feilotter HE, Nagai MA, Boag AH, Eng C, Mulligan LM. Analysis of PTEN and the $10 q 23$ region in primary prostate carcinomas. Oncogene. 1998;16(13):1743-8.

33. Rashmi R, Deselm C, Helms C, Bowcock A, Rogers BE, Rader J, et al. AKT inhibitors promote cell death in cervical cancer through disruption of mTOR signaling and glucose uptake. PLoS One. 2014;9(4):e92948.

34. Petersen S, Rudolf J, Bockmühl U, Gellert K, Wolf G, Dietel M, et al. Distinct regions of allelic imbalance on chromosome 10q22-q26 in squamous cell carcinomas of the lung. Oncogene. 1998;17(4):449-54.

35. Kubo Y, Urano Y, Hida Y, Arase $S$. Lack of somatic mutation in the PTEN gene in squamous cell carcinomas of human skin. J Dermatol Sci. 1999;19(3):199-201.

36. Okami K, Wu L, Riggins G, Cairns P, Goggins M, Evron E, et al. Analysis of PTEN/MMACl alterations in aerodigestive tract tumors. Cancer Res. 1998;58(3):509-11.

37. Hu YC, Lam KY, Tang JC, Srivastava G. Mutational analysis of the PTEN/MMACl gene in primary oesophageal squamous cell carcinomas. Mol Pathol. 1999;52(6):353-6.

38. Wang L, Wang WL, Zhang Y, Guo SP, Zhang J, Li QL. Epigenetic and genetic alterations of PTEN in hepatocellular carcinoma. Hepatol Res. 2007;37(5):389-96.

39. Zhou XP, Gimm O, Hampel H, Niemann T, Walker M, Eng C. Epigenetic PTEN silencing in malignant melanomas without PTEN mutation. Am J Pathol. 2000; 157(4): $1123-8$.

40. Ojesina Al, Lichtenstein L, Freeman SS, Pedamallu CS, ImazRosshandler I, Pugh TJ, et al. Landscape of genomic alterations in cervical carcinomas. Nature. 2014;506(7488):371-5.

41. Lin $H$, Bondy ML, Langford LA, Hess KR, Delclos GL, Wu X, et al. Allelic deletion analyses of MMAC/PTEN and DMBT1 loci in gliomas: relationship to prognostic significance. Clin Cancer Res. 1998;4(10):2447-54.

42. Lee Jl, Soria JC, Hassan KA, El-Naggar AK, Tang X, Liu DD, et al. Loss of PTEN expression as a prognostic marker for tongue cancer. Arch Otolaryngol Head Neck Surg. 2001;127(12):1441-5.

43. Freeman DJ, Li AG, Wei $G$, Li HH, Kertesz N, Lesche R, et al. PTEN tumor suppressor regulates p53 protein levels and activity through phosphatase-dependent and -independent mechanisms. Cancer Cell. 2003;3(2):1 17-30.

44. Shiohara S, Shiozawa T, Miyamoto T, Feng YZ, Kashima H, Kurai M, et al. Expression of cyclins, p53, and Ki-67 in cervical squamous cell carcinomas: overexpression of cyclin $\mathrm{A}$ is a poor prognostic factor in stage Ib and II disease. Virchows Arch. 2005;446(6):626-33.

45. Korolenkova LI, Stepanova EV, Ermilova VD, Baryshnikov Alu, Briuzgin VV. [Ki-67 expression, thymidine phosphorylase and PTEN in intraepithelial cervical carcinoma]. Vopr Onkol. 201 1;57(2):199-203. Russian.

46. Saver G, Deissler H. Angiogenesis: prognostic and therapeutic implications in gynecologic and breast malignancies. Curr Opin Obstet Gynecol. 2003;15(1):45-9. 